\title{
Quality of ultra-high temperature treated chocolate milk manufactured in Bangladesh
}

\author{
MA Sabbir ${ }^{1}$, R Habib $^{1 *}$, MH Rashid ${ }^{1}$, MF I mam ${ }^{2}$ \\ ${ }^{1}$ Department of Dairy Science, Bangladesh Agricultural University, Mymensingh 2202; ${ }^{2}$ Department of \\ Agricultural Statistics, Bangladesh Agricultural University, Mymensingh 2202, Bangladesh
}

\begin{abstract}
Quality of ultra-high temperature (UHT) treated chocolate milk manufactured by different manufacturing companies of Bangladesh was evaluated. The milk samples were collected from retail shops of different markets supplied by three major dairy brands namely Aarong, Starship and Milkman. From the organoleptic tests it was found that there were no significant variation in consistency, but significant variations $(p \leq 0.05)$ were found in case of flavor and colour and appearance, $\mathrm{pH}$ and solids-not-fat (SNF) content showed insignificant difference, while significant variations at different levels $(p<0.01$ to 0.05) were found in all other chemical parameters like contents of total solids, fat, protein, ash and carbohydrate (mixed sugar). There was no evidence of presence of bacteria (total viable bacteria and coliform bacteria) in any of the samples. Considering all of organoleptic, chemical and microbiological properties of the samples of UHT chocolate milks, it could be concluded that Starship UHT chocolate milk was better and more acceptable followed by that supplied by Milkman. It could be suggested that to obtain quality UHT chocolate milk proper method, composition of ingredients and also the strict hygienic and sanitary measures should be followed.
\end{abstract}

Key words: UHT, chocolate milk, quality.

Bangladesh Animal Husbandry Association. All rights reserved. Bang. J. Anim. Sci. 2015.45 (1): 128-131

\section{I ntroduction}

Flavored milk products are very popular in Bangladesh and cover a considerable portion of total dairy food consumption in the country, especially the chocolate milk. Chocolate milk is sweetened milk flavored with chocolate or cocoa which has a dark color and chocolaty flavor. The raw materials used range from low-fat milk to full-cream milk. Chocolate milk now supplied to the market are mostly ultra-high temperature (UHT) treated to increase shelf-life.

The nutritive value of UHT chocolate milk compares in the same way as that of whole milk. It contains most of the essential nutrients, which are required for normal functioning of the body system for all ages of people. The main constituents of chocolate milk are water, proteins, fat, carbohydrate and minerals ( $\mathrm{Na}, \mathrm{K}$, $\mathrm{P}, \mathrm{Ca}, \mathrm{Mg}, \mathrm{Mn}$, etc.). Besides the above constituents chocolate milk also contains considerable amount of fat-soluble vitamins (Vitamin $A, D, E, K$ ) and water soluble vitamins (B complex and $\mathrm{C}$ ). Addition of sucrose as sweetener also improves the energy value from growing children.

Bangladesh has been rather late in appreciating importance of chocolate milk. Fortunately, a number of renowned milk manufacturing companies (BRAC Dairy and Food Project, Abul Khair Condensed Milk \& Beverage Ltd., Akij Dairy farm, etc.) have already been established in Bangladesh. They produce UHT Chocolate milk under different trade names which widely available in the retail shops of different cities and towns all over Bangladesh. At the same time, the nutritive value of UHT chocolate milk depends on its cleanliness, purity and wholesomeness. So, it is essential to monitor the quality of UHT chocolate milks that supplied by different manufacturers in Bangladesh. No research work has ever been conducted to monitor the quality of this product in this country. Hence the present experiment was carried out to evaluate the quality of UHT chocolate milks produced by different dairy manufacturers of Bangladesh. 


\section{Materials and Methods}

The study was carried out at the Dairy Chemistry and Dairy Technology Laboratory of the Department of Dairy Science, Bangladesh Agricultural University, Mymensingh and BRAC Dairy and at the Quality Control Laboratory Food Project, Gazipur during the period of October 12 to December 4, 2014. UHT chocolate milk packaged in tetra pak as produced by three renowned milk processing companies of Bangladesh were chosen. Three types of samples under different trade names were found in different retail shops: (A) Aarong by BRAC Dairy and Food Project; (B) Starship by Abul Khair Condensed Milk \& Beverage Limited; and (C) Milkman by Pran Dairy Limited.

After collection of the selected samples from different retail shops, all the packaged samples were opened aseptically so that there were no contaminations. A total of 27 , three samples from each of the three brands in three separate trials were collected. Samples were analyzed by a panel of experienced judges for organoleptic scores (flavor, consistency, color and appearance), chemical composition $(\mathrm{pH}$, contents $(\mathrm{g} / \mathrm{kg})$ of total solids, fat, solids-notfat, protein, carbohydrate, and ash), microbiological qualities (total viable count, and coliform count). The Analysis of variance (ANOVA) was done as using completely Randomized Design (Steel et al. 1997) by the SPSS statistical package. Least significant Difference (LSD) values were also determined to rank the samples.

\section{Results and Discussion}

Flavor scores of the experimental UHT chocolate milks were $43.00 \pm 2.65, \quad 30.00 \pm 5.00$ and $36.67 \pm 2.89$, respectively (Table1). There was a significant difference $(p \leq 0.05)$ among the flavor scores. The score was highest in case of sample A (Aarong) UHT chocolate milk, and the lowest for sample B (Starship) UHT chocolate milk. In general, all the samples got high scores for flavor. The variation in the flavor of chocolate milk depends on several factors viz., intensity of heating, quality of raw materials, etc., which agrees with the works of Kishor et al. (2007), Mohr et al. (1979) and Huang (1998).

The average consistency score with their standard deviations for UHT chocolate milks were $27.33 \pm 1.15,27.00 \pm 2.00$ and $25.33 \pm 1.15$, respectively (Table1). Statistical analysis showed that there was no significant difference among the consistency scores of different types of UHT chocolate milk samples. The slight variation in consistency score of UHT chocolate milk of different brands could be attributed to different levels of heat treatment as well as variations in manufacturing process.

Color and appearance score for the experimental samples were $17.33 \pm 1.15$, $18.67 \pm 0.58$ and $16.00 \pm 1.00$, respectively (Table 1). Statistical analysis showed that there were significant differences $(p \leq 0.05)$ among the color and appearance score of different UHT chocolate milk samples. Color and appearance score was the highest in case of sample B and lowest for sample $C$. These variations could be attributed to the concentration and quality cocoa used in making the product. The results experiment support the findings of Huang (1998) who reported that addition of more liquor chocolate improved the color, flavor and appearance scores of chocolate milk.

The mean values for $\mathrm{pH}$ of UHT chocolate milks (Table 2) were $6.53 \pm 0.02,6.53 \pm 0.03$ and $6.54 \pm 0.02$, respectively. Statistical analysis showed that there was insignificant difference among the $\mathrm{pH}$ of different types of chocolate milks. Mean value of $\mathrm{pH}$ was the highest for UHT chocolate milk of the Milkman brand, whereas that for the Aarong brand was the lowest. This could be explained by the variation in the initial $\mathrm{pH}$ values of raw milk, total solids content and use of acidity regulators in the products.

Total solids (TS) content of UHT chocolate milks (Table 2) were $130.73 \pm 1.52,142.07 \pm 0.67$ and $143.87 \pm 1.11 \mathrm{~g} / \mathrm{kg}$ respectively, and varied significantly $(p \leq 0.01)$. It was observed that the average value of TS of chocolate milk $C$ was significantly high, and that of A was significantly lower. The results agree with that reported by De (1980). 
Table 1. Comparison of organoleptic scores (Mean \pm SD) of UHT chocolate milks manufactured by different dairy companies in Bangladesh.

\begin{tabular}{lcccccc}
\hline \multirow{2}{*}{$\begin{array}{l}\text { Organoleptic } \\
\text { parameter }\end{array}$} & \multicolumn{2}{c}{ Score obtained } & LSD & $\begin{array}{c}\text { Level of } \\
\text { significance }\end{array}$ \\
\cline { 2 - 5 } & $\begin{array}{c}\text { Sample A } \\
\text { (Aarong) }\end{array}$ & $\begin{array}{c}\text { Sample B } \\
\text { (Starship) }\end{array}$ & $\begin{array}{c}\text { Sample C } \\
\text { (Milkman) }\end{array}$ & & \\
\hline Flavor (50) & $43.00^{\mathrm{a}} \pm 2.65$ & $30.00^{\mathrm{b}} \pm 5.00$ & $36.67^{\mathrm{ab}} \pm 2.89$ & 7.326 & $*$ \\
Consistency (30) & $27.33 \pm 1.15$ & $27.00 \pm 2.00$ & $25.33 \pm 1.15$ & - & $\mathrm{NS}$ & $*$ \\
Color and Appearance (20) & $17.33^{\mathrm{ab}} \pm 1.15$ & $18.67^{\mathrm{a}} \pm 0.58$ & $16.00^{\mathrm{b}} \pm 1.00$ & 1.883 & $*$ \\
\hline
\end{tabular}

a,b,c Means with different superscripts in the same row differ significantly: * =Significant at $5 \%$ level; NS = Nonsignificant.

Table 2. Comparison of different types of UHT chocolate milk manufactured by different dairy companies in Bangladesh.

\begin{tabular}{|c|c|c|c|c|c|}
\hline \multirow{2}{*}{$\begin{array}{l}\text { Chemical } \\
\text { parameters }\end{array}$} & \multicolumn{3}{|c|}{ Composition (Mean \pm SD) } & \multirow{2}{*}{$\begin{array}{l}\text { LSD } \\
\text { value }\end{array}$} & \multirow{2}{*}{$\begin{array}{l}\text { Level of } \\
\text { significance }\end{array}$} \\
\hline & $\begin{array}{l}\text { Sample A } \\
\text { (Aarong) }\end{array}$ & $\begin{array}{l}\text { Sample B } \\
\text { (Starship) }\end{array}$ & $\begin{array}{l}\text { Sample C } \\
\text { (Milkman) }\end{array}$ & & \\
\hline $\mathrm{pH}$ & $6.53 \pm 0.02$ & $6.53 \pm 0.03$ & $6.54 \pm 0.02$ & - & NS \\
\hline Fat $(\mathrm{g} / \mathrm{kg})$ & $7.00^{c} \pm 0.51$ & $17.33^{b} \pm 0.58$ & $20.67^{a} \pm 1.15$ & 1.824 & $* *$ \\
\hline SNF $(\mathrm{g} / \mathrm{kg})$ & $123.73 \pm 0.55$ & $124.73 \pm 0.59$ & $123.20 \pm 0.70$ & - & NS \\
\hline Protein $(\mathrm{g} / \mathrm{kg})$ & $32.37^{b} \pm 0.15$ & $32.97^{a} \pm 0.15$ & $32.57^{b} \pm 0.21$ & 0.346 & $*$ \\
\hline Carbohydrate $(\mathrm{g} / \mathrm{kg})$ & $83.50^{\mathrm{ab}} \pm 0.60$ & $84.33^{a} \pm 0.58$ & $82.50^{b} \pm 0.50$ & 1.052 & $\&$ \\
\hline Ash $(\mathrm{g} / \mathrm{kg})$ & $7.87 \pm 0.25$ & $7.43^{\mathrm{b}} \pm 0.12$ & $8.13^{\mathrm{a}} \pm 0.12$ & 0.275 & $* *$ \\
\hline TS $(g / k g)$ & $130.73^{b} \pm 1.52$ & $142.07^{\mathrm{a}} \pm 0.67$ & $143.87^{\mathrm{a}} \pm 1.11$ & 1.824 & $* *$ \\
\hline
\end{tabular}

a,b,c Means with different superscripts in the same row differ significantly: **, significant at $1 \%$ level, * , significant at $5 \%$ level; NS, non-significant

The fat contents of UHT chocolate milks were $7.00 \pm 1.00, \quad 17.33 \pm 0.58$ and $20.67 \pm 1.15 \mathrm{~g} / \mathrm{kg}$, respectively (Table 2 ). Differences were highly significant $(p<0.01)$ among those mean values. It was clear that $C$ type UHT chocolate milk had significantly high amount of fat, while the lowest fat content was found in A type. So it was found that a wide variation of the fat content existed among different brands of UHT chocolate milk. Low fat content in the product of Aarong brand could be attributed to the use of partly skimmed milk. This result did not agree with the finding of Salama (1996), who reported that the fat percentage of low fat milk chocolate ranges from $2.0 \%$ to $3.0 \%$. Mann (1982) also found the mean fat per cent of low fat chocolate milk to be $2.5 \%$.

Solids-not-fat (SNF) contents of UHT chocolate milks were $123.73 \pm 0.55,124.73 \pm 0.59$ and $123.20 \pm 0.70 \mathrm{~g} / \mathrm{kg}$ respectively (Table 2 ). No significant difference was observed among the SNF contents. All the samples had a high SNF contents which could be attributed to the contents of protein and carbohydrates.
Protein contents of UHT chocolate milks were $32.37 \pm 0.15,32.97 \pm 0.15$ and $32.57 \pm 0.21 \mathrm{~g} / \mathrm{kg}$, respectively (Table 2 ). Statistical analysis showed that there was a significant difference 0.05 ) among the protein contents of different UHT chocolate milk samples. Sample B had the highest protein content, whereas sample A showed the lowest protein content. Dijk et al (1983) reported that average protein content of low fat chocolate milk was $3.46 \%$. Monti et al. (1978) in another study found the average protein content of chocolate milk to be $3.45 \%$. The result of this study agrees with these findings. In general, all the samples had protein contents typical for chocolate milk, which could be due to the use of good quality raw milk or milk solids.

Carbohydrate contents of chocolate milk samples were $83.50 \pm 0.50,84.33 \pm 0.58$ and $82.50 \pm 0.50$ $\mathrm{g} / \mathrm{kg}$, respectively (Table 2 ) with a significant variation ( $1 \leq 0.05)$. Sample B contains higher sugar levels as compare to others. The carbohydrate contents of UHT chocolate milk 
agrees with the findings of Salama (1996) who reported that average mixed sugar content of chocolate milk ranged between 8-9\%.

Ash content of different UHT chocolate milk samples were 7.87 $\pm 0.25,7.43 \pm 0.12$ and $8.13 \pm 0.12 \mathrm{~g} / \mathrm{kg}$, respectively (Table 2 ). It was observed that $\mathrm{C}$ type of UHT chocolate milk had the highest amount $(p<0.01)$ of ash. On the other hand, lowest ash content was found in B type. This could be attributed to the quality of chocolate powder used, as well as use of buffering salts.

There was no evidence of the presence of viable bacteria or coliform bacteria in any of the UHT chocolate milks produced by different manufacturers. This could be attributed to proper UHT sterilization and aseptic packaging.

\section{Conclusion}

Considering overall organoleptic, compositional and microbiological properties of the samples of UHT chocolate milks, the Starship UHT chocolate

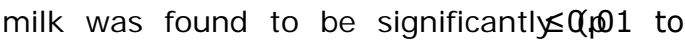
0.05 ) better. It may be suggested that, in order to obtain quality UHT chocolate milks all aspect of good manufacturing practice like quality raw material, machinery, manufacturing method and packaging should be followed. In essence, all of the brands produced UHT chocolate milks with acceptable organoleptic and microbial qualities, though there was a wide variation in fat contents.

\section{References}

De S (1980). Outlines of dairy technology. $1^{\text {st }}$ edition. Oxford Press, New Delhi.

Dijk G, Van JDE, Hoogh JV (1983). The composition of UK. Confectionery cocoa products. Journal of Agricultural Economics. 45: 896.

Hough GR, Sanchez (1998). Descriptive analysis and external preference mapping of powdered chocolate milk. Dairy Science Abstracts. 60: 903.

Kishor J, Gedam I, Rajendra K, Prasad L, Vijay VK (2007). The study on UHT processing of milk: a versatile option for rural sector. World J ournal of Dairy and Food Sciences. 2: 49-53.

Mann, EJ (1978). Flavoured milk and beverages. Dairy Industries International.44(12) 1825.

Mohr WR, Heiss G, Zieglede F, Biebl J (1979). Improvement of the aroma of milk containing and milk free chocolate mass. Dairy Science Abstracts. 42: 102-108.

Monti JC, Jost R (1978). Quality determination of flavored milk in connection with standardization of skim milk. Journal of Dairy Science. 61: 1233-1237.

SalamaFMM(1996). Production of new chocolate milk drinks. Egyptian Journal of Food Science. 22: 357-367.

Steel RGD, Torrie JH, Dickey DA (1997). Principles and procedure of statistics: a biometrical approach. $3^{\text {rd }}$ edition. The McGraw-Hill Companies, Inc., New York. 